\title{
CALENDAR EFFECTS ON THE REAL ESTATE MARKET
}

\author{
Justyna Brzezicka, M.Sc. \\ Faculty of Geodesy and Land Management \\ University of Warmia and Mazury in Olsztyn \\ e-mail: justyna.brzezicka@uwm.edu.pl
}

Radosław Wiśniewski, assoc. prof., PhD

Faculty of Geodesy and Land Management

University of Warmia and Mazury in Olsztyn

e-mail:danrad@uwm.edu.pl

\begin{abstract}
Social and economic phenomena that rely on "soft" factors to explain the market reality supply highly valuable observations. Behavioral elements should not be omitted in analyses of the real estate market because the latest developments in behavioral sciences significantly contribute to our understanding of this market.

The popularity of behavioral research in social and economic sciences provokes an examination of the significance of behavioral analyses on the real estate market. As an object of social and economic inquiry, the property market can benefit from recent achievements in behavioral sciences which expand the explanatory potential of studies based on the neoclassical model.

This paper analyzes calendar anomalies, generally referred to as calendar effects, on the real estate market. This phenomenon has been observed on the capital market and has been investigated and described by behavioral finance. The research hypothesis tested in this study is that calendar effects are present on the real estate market.

This paper aims to:

1) review calendar effects as model phenomena on the real estate market,

2) determine whether calendar effects occur on the real estate market and, if so, identify those anomalies,

3) determine whether and to what extent the real estate market is governed by seasonal diversity,

4) explain the significance of calendar effects to the real estate market.

Research goals were pursued based on analyses of real estate transactions conducted in Olsztyn between 2004 and 2011.
\end{abstract}

Key words: calendar effects, behavioral finance, real estate market.

JEL Classification: R30, D03, D70.

Citation: Brzezicka J., Wiśniewski R., (2013), "Calendar effects on the real estate market", Real Estate Management and Valuation, vol. 21, no. 2, pp. 13-21.

DOI: 10.2478/remav-2013-0012

\section{Introduction}

More than fifty years ago, it became evident that capital markets do not explain empirical evidence based on classical economic models. Those observations laid the foundations for the development of a new research field: "behavioral finance has combined the classical study of finance with psychology and sociology to expand our understanding of investor decision-making on the capital market" 
(CZERWONKA, GORLEWSKI 2012, p. 38) and "its effects on prices, return rates and capital investments" (KOPPEL 2012/2011, p. 36).

The real estate market is a type of capital market. The effectiveness of behavioral research in explaining real estate market phenomena should be investigated. It should be noted, however, that the real estate market, in contrast to the stock market, is imperfect. This paper will attempt to answer the following questions: is the real estate market governed by the principles applicable to the capital market and can behavioral finance explain investor decisions on the real estate market?

\section{Calendar effects on the capital market as explained by behavioral finance}

A series of anomalies, known as calendar effects, have been identified and described by behavioral finance based on the observation that selected seasons of the year bring higher rates of return on investments. "Calendar anomalies reveal the presence of regularities in stock returns over time" (SZYSZKA 2009, p. 151). The repeatability of the observed phenomena is of essence to our investigation.

The presence of calendar effects on capital markets has been confirmed by numerous studies of the Warsaw Stock Market (GROTOWSKI 2008; ORDAK 2000; SEKUŁA 2003; SIWEK 2000) and stock markets in Asian (HoLDEN et al. 2005), Arab (AL-HAJIEH et al. 2011) and European countries (SAR 2003).

A brief overview of calendar effects observed on capital markets is presented in Table 1.

Calendar effects on capital markets - description and explanation

Table 1

Effect Description Explanation

\begin{tabular}{|c|c|c|}
\hline $\begin{array}{l}\text { January } \\
\text { effect, } \\
\text { month-of- } \\
\text { the-year } \\
\text { effect, end- } \\
\text { of-the-year } \\
\text { effect }\end{array}$ & $\begin{array}{l}\text { In January, average return rates } \\
\text { are relatively high (ŁON 2006, p. } \\
\text { 30), and they often represent the } \\
\text { highest average rates of return in } \\
\text { the year (CZERWONKA, GORLEWSKI } \\
\text { 2012, p. 154). }\end{array}$ & $\begin{array}{l}\text { A hypothesis postulating that depreciated stock is } \\
\text { sold at the end of the year to produce tax- } \\
\text { deductible losses (Szyszka 2009, p. 166). } \\
\text { Decreasing transaction costs, window dressing } \\
\text { (funds push up share prices to improve their } \\
\text { annual performance reports), synchronicity with } \\
\text { business cycles, lower real rates of return at the } \\
\text { beginning of the year (GU 2003, p. 396). }\end{array}$ \\
\hline $\begin{array}{l}\text { Weekday } \\
\text { effect, } \\
\text { weekend } \\
\text { effect }\end{array}$ & $\begin{array}{l}\text { "Stock prices increase on Friday } \\
\text { and decrease on Monday more } \\
\text { than on any other day of the } \\
\text { week" (ZIELONKA 2011, p. 40). }\end{array}$ & $\begin{array}{l}\text { The highest variability in stock prices is observed } \\
\text { around the weekend - on Thursdays, Fridays and } \\
\text { Mondays (KIYMAZ, BERUMENT 2003, p. 377). }\end{array}$ \\
\hline $\begin{array}{l}\text { Turn-of-the- } \\
\text { month effect }\end{array}$ & $\begin{array}{l}\text { Return rates are higher directly } \\
\text { before and after the turn of the } \\
\text { month. }\end{array}$ & $\begin{array}{l}\text { Search for correlations between a high market } \\
\text { and the payment of wages in the middle of the } \\
\text { month in some countries, such as Singapore } \\
\text { (CZERWONKA, GORLEWSKI 2012, p. 157). }\end{array}$ \\
\hline $\begin{array}{l}\text { Sell in May } \\
\text { and go away }\end{array}$ & $\begin{array}{l}\text { Assets are sold in early May } \\
\text { before the summer holidays and } \\
\text { are typically repurchased around } \\
\text { Halloween (CHUDZYŃSKA-STĘPIEŃ } \\
\text { 2012, p. 136). }\end{array}$ & $\begin{array}{l}\text { Investors have a low interest in the stock market } \\
\text { during the summer. }\end{array}$ \\
\hline $\begin{array}{l}\text { Mark Twain } \\
\text { effect }\end{array}$ & $\begin{array}{l}\text { Stock returns are lowest in } \\
\text { October. }\end{array}$ & $\begin{array}{l}\text { The name is based loosely on a quote by Mark } \\
\text { Twain: "October. This is one of the peculiarly } \\
\text { dangerous months to speculate in stocks. The others } \\
\text { are July, January, September, April, November, } \\
\text { May, March, June, December, August, and } \\
\text { February" (CHUDZYNSKA-STĘPIEN 2012, p. 137). }\end{array}$ \\
\hline
\end{tabular}

Source: own study

\section{Calendar effects on the real estate market - experimental part}

\subsection{Data and Methods}

To the authors' best knowledge, the presence of calendar effects on the real estate market has not been investigated to date. The following procedure was adopted to investigate calendar effects: 
1. Stage I - preliminary selection of data.

1.1 Selection of market,

1.2 Selection of the type of analyzed data (objective scope, subjective scope, type of real estate, terms of transaction, other),

1.3 Selection of the analyzed period,

1.4 Other.

2. Stage II - detailed selection of data.

2.1 Selection of the analyzed calendar effect,

2.2 Selection of the period corresponding to the analyzed calendar effect,

2.3 Selection of research focus areas (qualitative analysis - based on transaction prices, quantitative analysis - based on transaction volumes; see section 3.3; other),

2.4 Other.

3. Stage III - identification of a calendar effect (statistical analysis).

3.1 Calendar effect is found - proceed to Stage II and/or Stage I to confirm the effect by testing a different data set,

3.2 Calendar effect is not found - proceed to Stage I to eliminate errors by testing a different data set. Determining the number of trials.

4. Stage IV - describing the calendar effect.

4.1 Seasonal effects with a behavioral explanation (which are not justified by market principles),

4.2 Seasonal effects without a behavioral explanation (which are justified by market principles).

The data was analyzed statistically and the search for calendar effects was performed with the use of two methods:

1) trial and error (Stages I-III) to identify the calendar effect,

2) expert method (Stage IV) to determine whether the calendar effect has a behavioral explanation.

Behavioral factors are rooted in psychology and, to a smaller extent, also sociology. These include emotions, temptations, the inability to gather and process information, cognitive ability, and impaired cognitive ability due to risk and/or uncertainty (BRZEZICKA, WIŚNIEWSKI 2013a).

We are dealing with behavioral factors when the behavior of an individual or a market cannot be explained by market principles. Market principles include market trends, cyclic phenomena, and changes in market procedures (legal procedures, recommendations for institutions financing investments), processes (changes in demand, liquidity, higher investment risk, inflation) and structures (new supervisory and financial authorities)" (BRZEZICKA, WIŚNIEWSKI 2013c). Calendar effects that can and cannot be explained by behavioral tendencies are identified based on observable market trends and market knowledge.

\subsection{Basic research premises}

Calendar effects on the real estate market were investigated based on data relating to property transactions concluded in Olsztyn in 2004-2011. The analyzed data consisted of transaction prices of real property quoted in the Register of Real Estate Prices and Values kept by the Olsztyn City Office. This study was based on the following basic premises:

1) Subjective scope: the parties to a standard transaction are individuals, legal entities or local government units. In a standard transaction, the prices of traded property were set based on that property's fair market value. Transactions with the State Treasury were not analyzed.

2) Objective scope: ownership of real estate (co-ownership, perpetual usufruct and share of perpetual usufruct were excluded).

3) Type of real estate: transactions involving the sale and purchase of undeveloped land intended for non-agricultural purposes (agricultural land was excluded).

4) Terms of the transaction: transactions conducted in line with free market principles (transactions concluded as part of an open bid or a no-bid procedure and non-market transactions were excluded).

5) Transactions with incomplete data and transactions where the price of property significantly diverged from fair market value were excluded. 


\subsection{Calendar effects on the real estate market}

Unlike on the capital market, calendar effects on the real estate market cannot be investigated based on return rates (excluding rental returns). The above results from the specific nature of the real estate market (permanence of location, permanence over time, long-term investments, capital intensity) and the objective of real estate transactions (real estate is traded mainly to satisfy housing needs rather than for speculative reasons). For this reason, the character of calendar effects had to be adapted to the specific nature of the real estate market. The search for calendar effects was conducted with the use of two methods:

1) method I (qualitative analysis) - calendar effects were determined based on transaction prices in each of the analyzed periods,

2) method II (quantitative analysis) - calendar effects were determined based on the volume of transactions concluded in each of the analyzed periods.

Three calendar effects on the real estate market have been identified, described and interpreted in this study:

1) The July effect - qualitative analysis,

2) Intramonth effect - qualitative and quantitative analysis,

3) April 2004 effect - quantitative analysis.

The analyzed effects do not represent a complete list of calendar effects on the real estate market.

\subsubsection{The July effect (qualitative analysis)}

In structural terms, the July effect is a month-of-the-year effect. The month-of-the-year effect (qualitative analysis) was investigated based on market prices, regardless of current market trends. Market trends do not affect the month-of-the-year effect. The objective of this study was to examine seasonal trends on the real estate market which do not require property valuation. This research method was adopted as the most conducive to observing seasonal trends on the real estate market. Data was sorted based on the described premises and covered a period from 2004 to 2010. Data for 2011 was incomplete (an insufficient number of transactions, unreliable data, no registered transactions in February - May and December) and therefore, was not included in the analysis.

Average monthly prices, determined based on the arithmetic mean, were used to identify the month effect (in qualitative analysis - price fluctuations in each month). Based on the evaluation of average market prices for each month and descriptive price statistics, data relating to transactions concluded in 2004-2007 and 2009 was qualified for the analysis. Data for 2008 and 2010 was incomplete (no registered transactions in selected months).

An analysis of market prices produced results which could not be used for comparative purposes. For this reason, the concept of a "relative price" was introduced as the ratio of the average price in a given month of the year to the average price in that year (average annual price $=100 \%$ ). The average annual price was defined as the arithmetic mean of all qualified transactions concluded in that year. Relative prices in the analyzed years are presented in Table 2. Descriptive statistics for relative prices are given in Table 3.

Table 2

Relative prices in each month of 2004-2007 and 2009

\begin{tabular}{cccccccccccc}
\hline Month & $2004^{*}$ & 2005 & 2006 & 2007 & 2009 & Month & $2004 *$ & 2005 & 2006 & 2007 & 2009 \\
\hline January & - & $103 \%$ & $123 \%$ & $69 \%$ & $77 \%$ & July & $101 \%$ & $100 \%$ & $99 \%$ & $163 \%$ & $98 \%$ \\
\hline February & $59 \%$ & $126 \%$ & $67 \%$ & $80 \%$ & $108 \%$ & August & $129 \%$ & $107 \%$ & $81 \%$ & $178 \%$ & $93 \%$ \\
\hline March & $72 \%$ & $98 \%$ & $82 \%$ & $71 \%$ & $78 \%$ & September & $126 \%$ & $143 \%$ & $95 \%$ & $118 \%$ & $150 \%$ \\
\hline April & $85 \%$ & $75 \%$ & $130 \%$ & $142 \%$ & $122 \%$ & October & $126 \%$ & $99 \%$ & $128 \%$ & $79 \%$ & $114 \%$ \\
\hline May & $49 \%$ & $89 \%$ & $122 \%$ & $86 \%$ & $139 \%$ & November & $76 \%$ & $113 \%$ & $62 \%$ & $32 \%$ & $37 \%$ \\
\hline June & $119 \%$ & $108 \%$ & $92 \%$ & $120 \%$ & $150 \%$ & December & $85 \%$ & $61 \%$ & $84 \%$ & $199 \%$ & $68 \%$ \\
\hline
\end{tabular}

* relative prices for 2004 were multiplied by an index of 0.91(6) due to an absence of data for January $\left[0.91(6)=1 / 12^{*} 11\right]$. Source: own study

Based on analyses of relative prices and descriptive statistics, the years 2004-2006 and 2009 were qualified for further analysis. Descriptive statistics for each month of the examined years are 
presented in Table 4. They were used to determine the presence of the July effect on the analyzed real estate market (Fig. 1).

Table 3

Descriptive statistics - relative prices in each month of 2004-2007 and 2009

\begin{tabular}{cccccc}
\hline Year & 2004 & 2005 & 2006 & 2007 & 2009 \\
\hline Average & 0.933 & 1.019 & 0.971 & 1.114 & 1.029 \\
\hline Standard error & 0.086 & 0.061 & 0.068 & 0.147 & 0.100 \\
\hline Median & 0.849 & 1.020 & 0.935 & 1.020 & 1.029 \\
\hline Standard deviation & 0.285 & 0.213 & 0.237 & 0.508 & 0.348 \\
\hline Sample variance & 0.081 & 0.045 & 0.056 & 0.258 & 0.121 \\
\hline Kurtosis & -1.452 & 0.912 & -1.331 & -0.814 & -0.431 \\
\hline Skewness & -0.058 & -0.064 & 0.153 & 0.343 & -0.254 \\
\hline Range & 0.799 & 0.818 & 0.677 & 1.673 & 1.137 \\
\hline Minimum & 0.490 & 0.610 & 0.621 & 0.317 & 0.366 \\
\hline Maximum & 1.290 & 1.428 & 1.298 & 1.990 & 1.503 \\
\hline Total & 10.266 & 12.231 & 11.652 & 13.364 & 12.345 \\
\hline Numerator & 11 & 12 & 12 & 12 & 12 \\
\hline
\end{tabular}

Source: own study

Descriptive statistics - in each month of 2004-2006; 2009

Table 4

\begin{tabular}{|c|c|c|c|c|c|c|c|c|c|c|c|c|}
\hline Month & Jan & Feb & Mar & Apr & May & Jun & Jul & Aug & Sep & Oct & Nov & Dec \\
\hline Average & 1.012 & 0.900 & 0.824 & 1.030 & 0.997 & 1.174 & 0.998 & 1.025 & 1.284 & 1.169 & 0.719 & 0.744 \\
\hline Standard error & 0.134 & 0.159 & 0.055 & 0.135 & 0.197 & 0.123 & 0.007 & 0.102 & 0.124 & 0.067 & 0.160 & 0.058 \\
\hline Median & 1.035 & 0.875 & 0.797 & 1.034 & 1.056 & 1.135 & 1.000 & 1.000 & 1.344 & 1.201 & 0.689 & 0.760 \\
\hline Standard deviation & 0.232 & 0.318 & 0.110 & 0.270 & 0.395 & 0.245 & 0.014 & 0.205 & 0.248 & 0.135 & 0.321 & 0.117 \\
\hline Sample variance & 0.054 & 0.101 & 0.012 & 0.073 & 0.156 & 0.060 & 0.000 & 0.042 & 0.061 & 0.018 & 0.103 & 0.014 \\
\hline Kurtosis & - & -4.21 & 1.979 & -5.05 & -0.95 & 1.066 & -0.27 & -0.09 & 0.554 & -0.49 & 0.828 & -4.09 \\
\hline Skewness & -0.44 & 0.211 & 1.288 & -0.03 & -0.67 & 0.866 & -0.69 & 0.615 & -1.11 & -0.97 & 0.537 & -0.32 \\
\hline Range & 0.463 & 0.664 & 0.255 & 0.543 & 0.896 & 0.580 & 0.032 & 0.479 & 0.558 & 0.295 & 0.769 & 0.239 \\
\hline Minimum & 0.769 & 0.593 & 0.723 & 0.755 & 0.490 & 0.924 & 0.980 & 0.811 & 0.946 & 0.989 & 0.366 & 0.610 \\
\hline Maximum & 1.232 & 1.256 & 0.978 & 1.298 & 1.387 & 1.503 & 1.012 & 1.290 & 1.503 & 1.284 & 1.135 & 0.849 \\
\hline Total & 3.035 & 3.599 & 3.294 & 4.121 & 3.989 & 4.697 & 3.991 & 4.100 & 5.136 & 4.676 & 2.878 & 2.978 \\
\hline Numerator & 3 & 4 & 4 & 4 & 4 & 4 & 4 & 4 & 4 & 4 & 4 & 4 \\
\hline
\end{tabular}

Source: own study

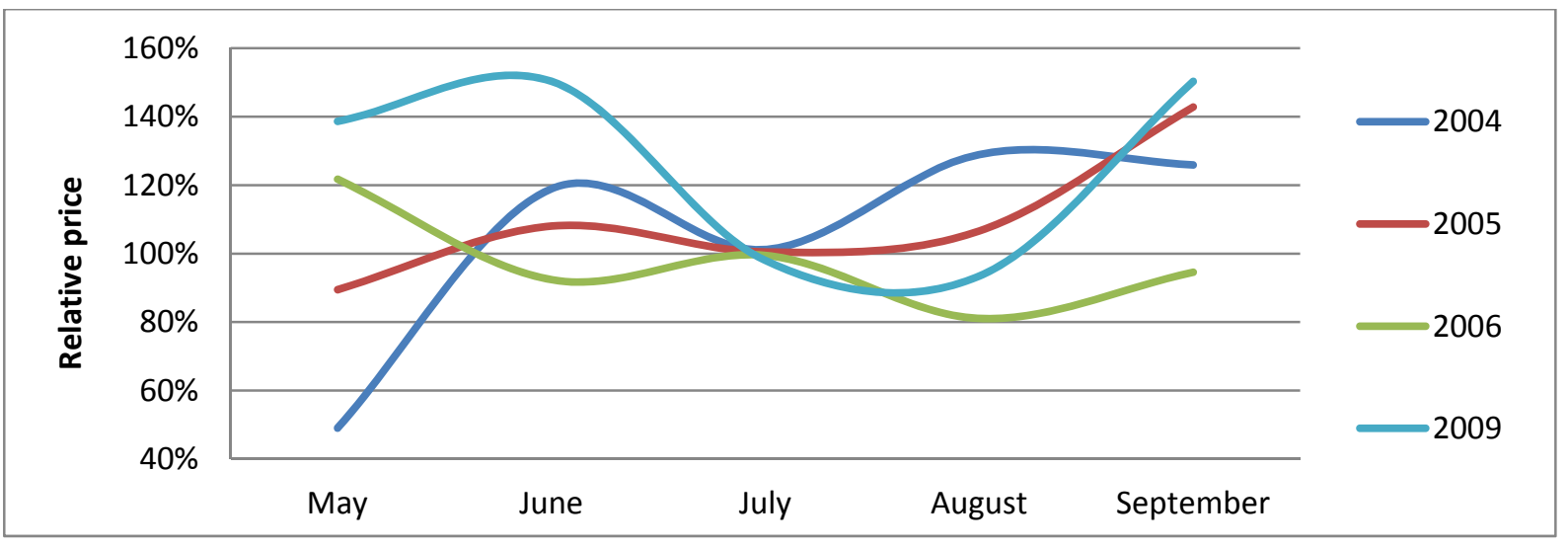

Fig. 1. July effect in 2004-2006 and 2009. Source: own study

The following trends can be observed based on the above analysis:

a) The analyzed data set suggests the presence of a July effect; 
b) As a summer month, July is characterized by the highest price stability. July is a quiet period which separates two "unstable" six-month periods on the real estate market.

c) July prices are representative of the annual average: sample variance -0.000 , standard deviation -0.014 , average relative price $-99.8 \%$ (average annual price $-100 \%$ ).

\subsubsection{The intramonth effect (qualitative and quantitative analysis)}

Qualitative and quantitative analyses were performed to determine the presence of intramonth effects on the real estate market. Monthly market trends do not affect prices. The objective of this analysis was to determine whether transactions concluded in three 10-day periods of a given month generate different prices and whether below- or above-average prices are quoted in specific parts of the month. To compare data from various periods, a "relative price" was introduced as the ratio of prices quoted in a given month to the average price in that month (average monthly price $=100 \%$ ). The intramonth effect was investigated in five months with the highest number of registered transactions (January 2007 - 16 transactions, April 2004 - 37 transactions, September 2008 - 16 transactions, April 2006 and June 2007 - 11 transactions each). The results are shown in Fig. 2. In months with 31 days, day 31 was included in the third part of the month.

The following correlations were observed:

a) The fewest transactions were concluded in the first 10-day part of the month. A higher number of transactions was noted in the second and third part of the month.

b) A growing trend was observed in all analyzed months (different months and years were examined). Prices tended to increase as the month progressed. All of the analyzed trends were growth trends, indicating that prices were expected to increase towards the end of the month.

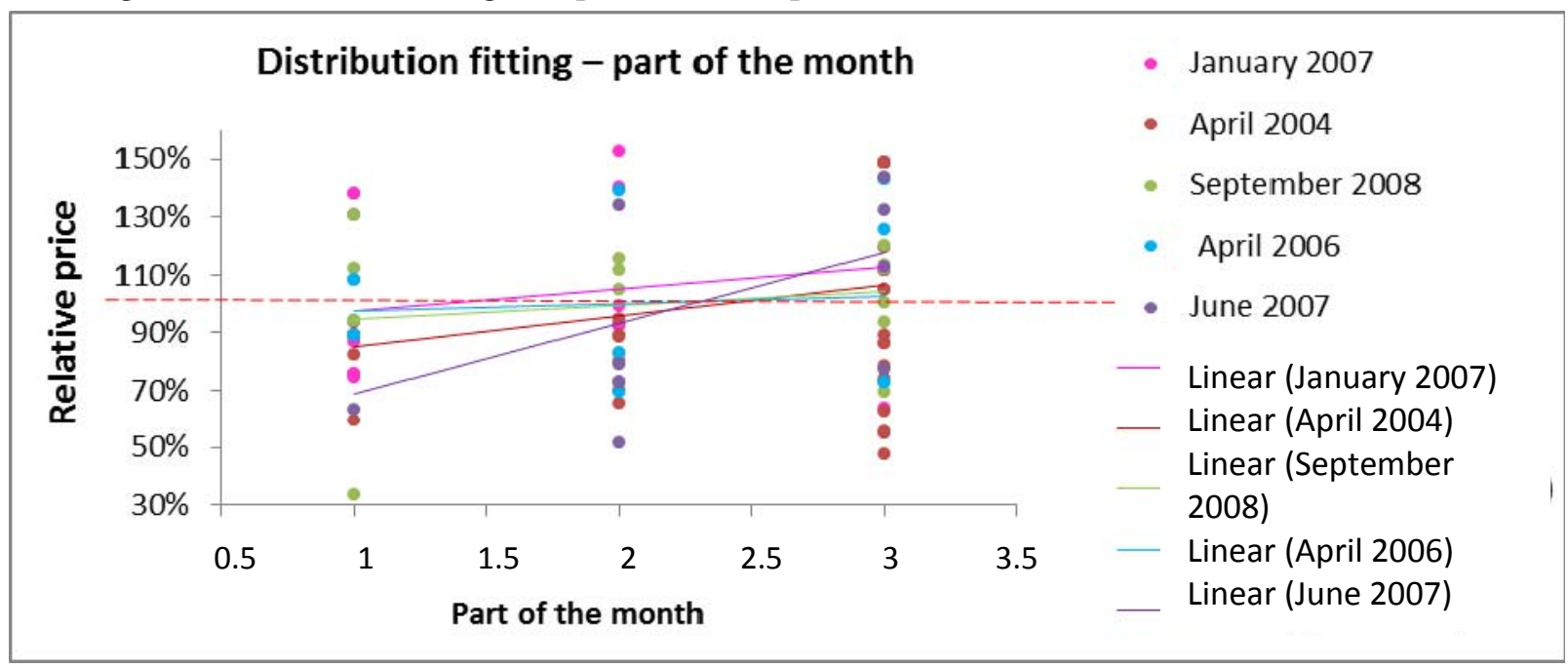

Fig. 2. Intramonth effect. Source: own study

\subsubsection{April 2004 effect (quantitative analysis)}

A quantitative analysis (percentage share of the number of transactions concluded in each month in the total number of transactions concluded during the year) revealed an above-average number of transactions in April 2004 (47\% of transactions in 2004 were concluded in April) in comparison with other months of 2004 and with April data for the remaining analyzed years (Fig. 3). The share of transactions concluded in each month of the year is presented in Table 5, while descriptive statistics are given in Table 6. The analysis covered 2004-2010, with 2011 not included due to incomplete data (refer to Tables 5 and 6).

Table 5

Percentage share of transactions concluded in each month in the total number of transactions concluded in 2004-2011.

\begin{tabular}{ccccccccc}
\hline Year & 2004 & 2005 & 2006 & 2007 & 2008 & 2009 & 2010 & 2011 \\
\hline January & $0 \%$ & $10 \%$ & $6 \%$ & $19 \%$ & $0 \%$ & $4 \%$ & $9 \%$ & $8 \%$ \\
\hline February & $4 \%$ & $4 \%$ & $3 \%$ & $12 \%$ & $0 \%$ & $8 \%$ & $0 \%$ & $0 \%$ \\
\hline March & $6 \%$ & $8 \%$ & $13 \%$ & $5 \%$ & $7 \%$ & $18 \%$ & $3 \%$ & $0 \%$ \\
\hline
\end{tabular}




\begin{tabular}{ccccccccc}
\hline April & $47 \%$ & $6 \%$ & $16 \%$ & $7 \%$ & $7 \%$ & $8 \%$ & $18 \%$ & $0 \%$ \\
\hline May & $5 \%$ & $10 \%$ & $7 \%$ & $12 \%$ & $4 \%$ & $16 \%$ & $0 \%$ & $4 \%$ \\
\hline June & $3 \%$ & $19 \%$ & $6 \%$ & $13 \%$ & $13 \%$ & $2 \%$ & $12 \%$ & $16 \%$ \\
\hline July & $4 \%$ & $8 \%$ & $9 \%$ & $7 \%$ & $7 \%$ & $6 \%$ & $0 \%$ & $24 \%$ \\
\hline August & $8 \%$ & $13 \%$ & $10 \%$ & $2 \%$ & $2 \%$ & $8 \%$ & $15 \%$ & $4 \%$ \\
\hline September & $14 \%$ & $2 \%$ & $12 \%$ & $5 \%$ & $36 \%$ & $6 \%$ & $18 \%$ & $4 \%$ \\
\hline October & $1 \%$ & $8 \%$ & $7 \%$ & $13 \%$ & $16 \%$ & $14 \%$ & $6 \%$ & $36 \%$ \\
\hline November & $6 \%$ & $4 \%$ & $1 \%$ & $1 \%$ & $0 \%$ & $2 \%$ & $9 \%$ & $4 \%$ \\
\hline December & $3 \%$ & $6 \%$ & $9 \%$ & $2 \%$ & $9 \%$ & $6 \%$ & $12 \%$ & $0 \%$ \\
\hline & $100 \%$ & $100 \%$ & $100 \%$ & $100 \%$ & $100 \%$ & $100 \%$ & $100 \%$ & $100 \%$ \\
\hline
\end{tabular}

Source: own study

Table 6

Descriptive statistics - percentage share of transactions concluded in each month in the total number of transactions concluded in 2004-2011

\begin{tabular}{ccccccccc}
\hline Year & 2004 & 2005 & 2006 & 2007 & 2008 & 2009 & 2010 & 2011 \\
\hline Average & 0.083 & 0.083 & 0.083 & 0.083 & 0.083 & 0.083 & 0.083 & 0.083 \\
\hline Standard error & 0.037 & 0.013 & 0.012 & 0.016 & 0.028 & 0.015 & 0.019 & 0.033 \\
\hline Median & 0.044 & 0.083 & 0.081 & 0.072 & 0.065 & 0.071 & 0.088 & 0.040 \\
\hline Mode & 0.038 & 0.083 & 0.059 & 0.120 & 0.065 & 0.082 & 0 & 0 \\
\hline Standard deviation & 0.127 & 0.044 & 0.042 & 0.056 & 0.096 & 0.053 & 0.066 & 0.114 \\
\hline Sample variance & 0.016 & 0.002 & 0.002 & 0.003 & 0.009 & 0.003 & 0.004 & 0.013 \\
\hline Kurtosis & 9.552 & 1.748 & -0.065 & -0.608 & 5.409 & -0.311 & -1.375 & 2.281 \\
\hline Skewness & 3.000 & 1.013 & 0.206 & 0.489 & 2.137 & 0.812 & 0.018 & 1.693 \\
\hline Range & 0.468 & 0.167 & 0.147 & 0.181 & 0.348 & 0.163 & 0.176 & 0.360 \\
\hline Minimum & 0 & 0.021 & 0.015 & 0.012 & 0 & 0.020 & 0 & 0 \\
\hline Maximum & 0.468 & 0.188 & 0.162 & 0.193 & 0.348 & 0.184 & 0.176 & 0.360 \\
\hline Total & 1 & 1 & 1 & 1 & 1 & 1 & 1 & 1 \\
\hline Numerator & 12 & 12 & 12 & 12 & 12 & 12 & 12 & 12 \\
\hline & & & & & & & &
\end{tabular}

Source: own study

The above-average number of transactions in April 2004 could be attributed to Poland's accession to the European Union on 1 May 2004. This causal relationship cannot be rationally justified by market principles because in the analyzed period, the demand for real estate was not driven by the availability of direct subsidies. The analyzed property were undeveloped land plots, but pursuant to the provisions of the Act of 26 January 2007 on agricultural and sugar subsidies, this form of financial aid was available only for agricultural land which was not analyzed in this study (ACT of 2007...). Poland had negotiated a derogation on the acquisition of real estate by non-citizens (Art. 8, point 2 of the ACT OF $1920 \ldots$...) to protect the market from a shock that could arise from a difference in land prices between Poland and the "old" EU countries. The fear that property prices would increase steeply was unjustified because the conclusion of a real estate transaction implies that one party disposes of property while the other party acquires it.

Attempts were made to explain the April 2004 effect and the behavior of real market participants based on behavioral factors. The fear that land prices would increase substantially after Poland's accession to the EU (manifested by a higher number of concluded transactions) could be explained by herd behavior, panic, speculation, or heuristic decision-making due to a lack of knowledge and emotions, which is why the highest number of transactions were concluded in the last days of April (Fig. 4). Behavioral research suggests that people are apt to act irrationally in problematic decisionmaking situations (BRZEZICKA, WIŚNIEWSKI 2013b). A qualitative analysis indicates that market prices (and relative prices) in April 2004 were higher than in March and May and that a speculative microbubble was created on the local property market (refer to Fig. 5 and 6).

It should be noted that the effect of April 2004 is not merely of a behavioral nature as it is also economically justified. Poland's accession to the European Union in the eyes of investors meant the 
reduction of political and economic risks of investing. This led to a fall in the rates of return and the rise of real estate prices and values.

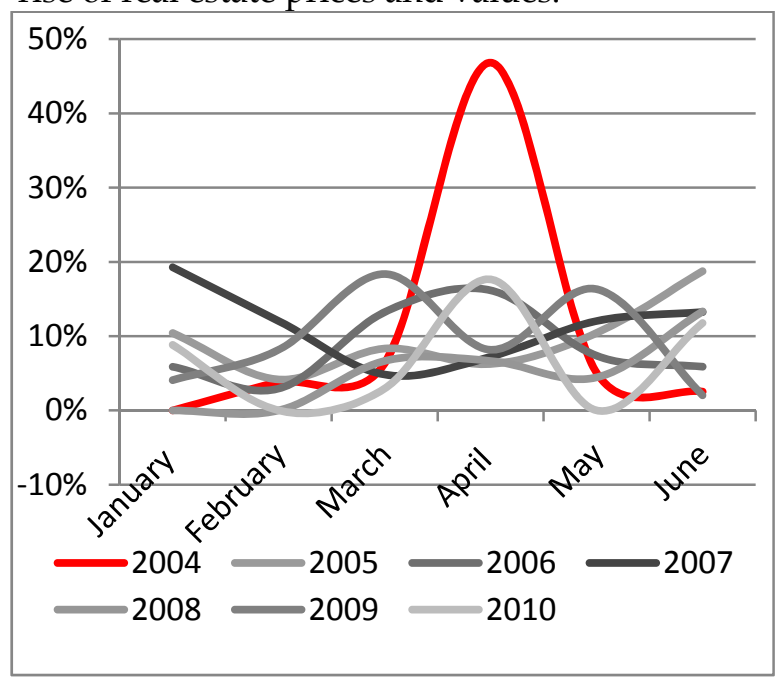

Fig. 3. Percentage share of transactions concluded in each month in the total number of transactions concluded during the year.

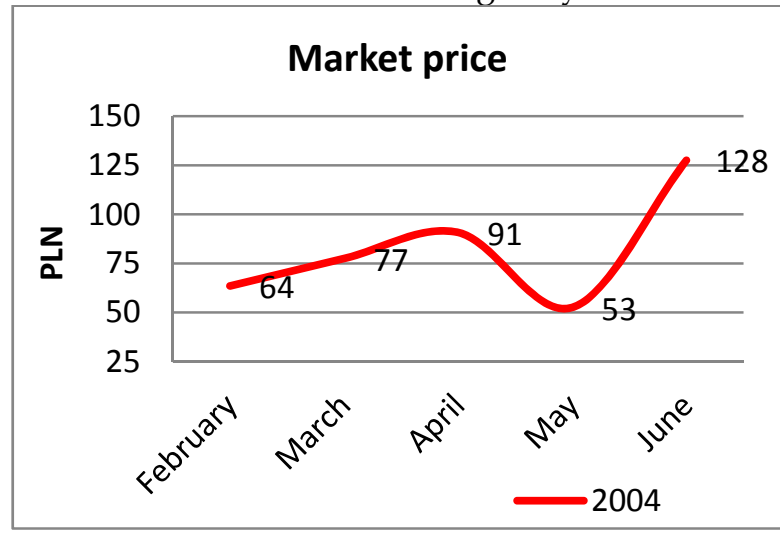

Fig. 5. Market prices in the first half of 2004. ${ }^{*}$ No transactions were registered in January 2004.

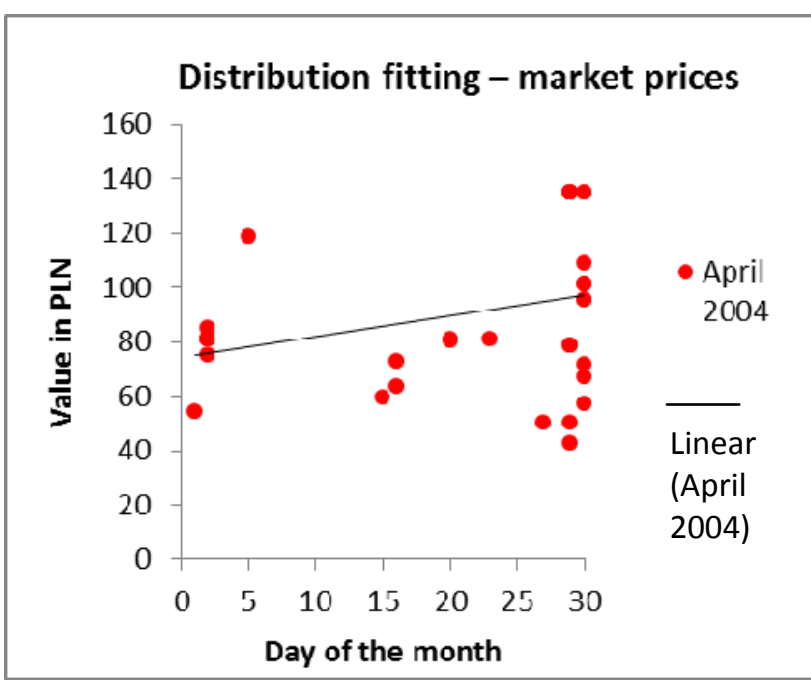

Fig. 4. Real estate transactions concluded in April 2004.

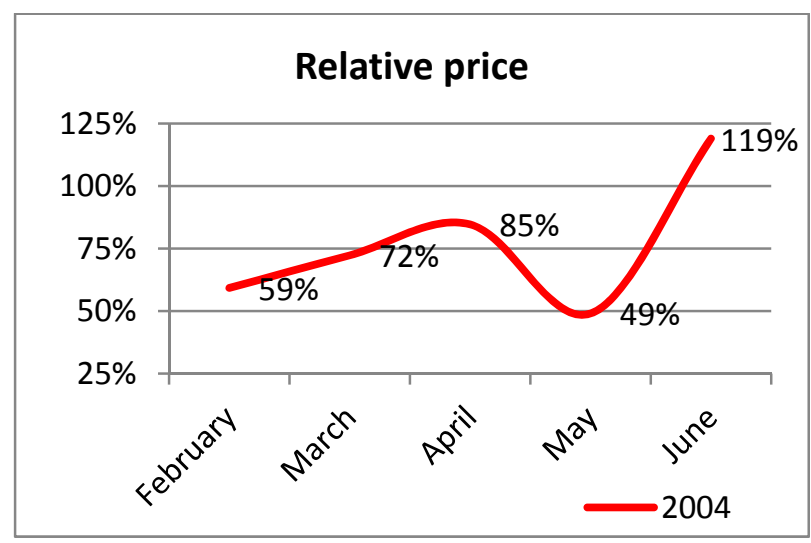

Fig. 6. Relative prices in the first half of 2004 .

* No transactions were registered in January 2004.

Source: own study

\section{Conclusions}

The results of both qualitative and quantitative analyses demonstrate the presence of calendar effects on the real estate market. Research limitations should, however, be mentioned. The research is not perfect because of the specific nature of the real estate market, such as a small number of transactions concluded each month, the locality of the market and the use of the arithmetic mean. Nevertheless, our findings can be used to formulate several conclusions.

Firstly, calendar effects exist on the real estate market and have a dual nature. Some effects (the July effect) can be explained by the fundamental principles that govern the market and its environment (low trading volume in the summer months), whereas others have both behavioral and economic explanations (the April 2004 effect).

Secondly, we identified the presence of intramonth effects on the real estate market. Fluctuations in property prices and transaction volumes were also noted during the course of a month, though this effect had never before been observed.

Thirdly, the presence of calendar effects has various consequences on the real property market. Individual and institutional investors can gather market data and analyze market anomalies to plan optimal transactions. Real estate agents, administrators and experts can effectively use their knowledge of the laws governing the prices and/or the volume of transactions in different seasons of the year. 
Lastly, our findings indicate that, in addition to strictly economic factors, the real estate market is also governed by behavioral elements which are determined by the complex human nature, cognitive abilities, emotions and preferences. Similarly to the capital market, the real estate market can also be modeled based on the behavioral approach. Thus, our observations justify the significance of earlier research that analyzed the behavioral aspects of market activity (BRZEZICKA, WIŚNIEWSKI 2012; 2013a; 2013c).

\section{References}

BRZEZICKA J., WiŚNIEWSKI R., 2012, Behawioralne aspekty rynku nieruchomości, Studia i Materiały Towarzystwa Naukowego Nieruchomości, nr 20 (2), s. 21-31.

BRZEZICKA J., WIŚNIEWSKI R., 2013a, Ekonomia behawioralna a rynek nieruchomości - teoria i praktyka, Psychologia ekonomiczna (article in press).

BRZEZICKA J., WIŚNIEWSKI R., 2013b, Homo oeconomicus a ekonomia behawioralna (under review in Cambridge Journal of Economics).

BRZEZICKA J., WIŚNIEWSKI R., 2013c, Bańka cenowa na rynku nieruchomości - aspekty behawioralne (in preperation, unpublished results).

AL-HAJIEH H., REDHEAD K., RODGERS T., 2011, Investor sentiment and calendar anomaly effects: A case study of the impact of Ramadan on Islamic Middle Eastern markets, Research in International Business and Finance, No. 25 (3), pp. 345-356.

CHUDZYŃSKA-STĘPIEŃ N., 2012, Petna paka na umarlaka, Forbes, No. 10, pp. 136-138.

CZERWONKA M., GORLEWSKI B., 2012, Finanse behawioralne. Zachowania inwestorów i rynku, Oficyna Wydawnicza SGH w Warszawie, Warszawa.

GROTOWSKI M., 2008, Efekty kalendarzowe na Giełdzie Papierów Wartościowych w Warszawie, Gospodarka Narodowa, No. 1-2, pp. 57-75.

Gu A. Y., 2003, The declining January effect: evidences from the U.S. equity markets, The Quarterly Review of Economics and Finance, No. 43 (2), pp. 395-404.

HOLDEN K., THOMPSON J., RUANGRIT Y., 2005, The Asian crisis and calendar effects on stock returns in Thailand, European Journal of Operational Research, No. 163 (1), pp. 242-252.

KIYMAZ H., BERUMENT H., 2003, The day of the week effect on stock market volatility: International evidence, Review of financial economics, No. 12, pp. 363-380.

KoPPEL R., 2012/2011, Inwestowanie a irracjonalny umyst. Podejmuj racjonalne decyzje w nieracjonalnym świecie inwestowania, Wyd. CeDeWu, Warszawa.

ŁON E., 2006, Barometr stycznia, Gazeta Bankowa, No. 8, pp. 30-33.

ORDAK G., 2000, Watpliwy urok stycznia, Rzeczpospolita, No. 47.

SAR N. L., 2003, Calendar Effects on the Amsterdam Stock Exchange, De Economist, No. 151 (3), pp. 271 292.

SEKUŁA P., 2003, Efekt stycznia na Giełdzie Papierów Wartościowych w Warszawie, Prace Naukowe Akademii Ekonomicznej we Wrocławiu, No. 974 (2), pp. 162-171.

SIWEK P., 2000, Efekt stycznia na rozwiniętych rynkach kapitatowych i na Giełdzie Papierów Wartościowych w Warszawie, Zeszyty Naukowe Akademii Ekonomicznej w Poznaniu, No. 4, pp. 150-163.

SZYSZKA A., 2009, Finanse behawioralne. Nowe podejście do inwestowania na rynku kapitatowym, Wydawnictwo Uniwersytetu Ekonomicznego w Poznaniu, Poznań.

ZIELONKA P., 2011, Giełda i psychologia. Behawioralne aspekty inwestowania na rynku papierów wartościowych, Wydanie III, Wyd. CeDeWu, Warszawa.

Ustawa z dnia 26 stycznia 2007 r. o ptatnościach do gruntów rolnych i płatności cukrowej, Dz. U. 2007 nr 35 poz. 217, z późn. zm. (Act of 26 January 2007 on agricultural and sugar subsidies, Journal of Laws, 2007 , No. 35, item 217, as amended).

Ustawa z dnia 24 marca 1920 r. o nabywaniu nieruchomości przez cudzoziemców, Dz. U. z 2004 r. nr 167, poz. 1758, z późn. zm. (Act of 24 March 1920 on the purchase of real estate by non-citizens, Journal of Laws, 2004, No. 167, item 1758, as amended).

Rejestr Cen i Wartości prowadzony przez Urząd Miasta w Olsztynie (Register of Real Estate Prices and Values kept by the Olsztyn City Office). 